OPEN ACCESS

Edited by:

Allan Randrup Thomsen, University of Copenhagen, Denmark

Reviewed by:

Philippe Gasque,

Centre Hospitalier Universitaire de La

Réunion, France

Amarendra Pegu,

National Institutes of Health (NIH),

United States

*Correspondence:

Lisa F. P. Ng

lisa_ng@immunol.a-star.edu.sg

Specialty section:

This article was submitted to Viral Immunology,

a section of the journal

Frontiers in Immunology

Received: 03 November 2019 Accepted: 05 February 2020

Published: 21 February 2020

Citation:

Poh CM, Chan Y-H and Ng LFP (2020) Role of T Cells in Chikungunya Virus Infection and Utilizing Their Potential in Anti-Viral Immunity.

Front. Immunol. 11:287. doi: 10.3389/fimmu.2020.00287

\section{Role of T Cells in Chikungunya Virus Infection and Utilizing Their Potential in Anti-Viral Immunity}

\author{
Chek Meng Poh ${ }^{1}$, Yi-Hao Chan ${ }^{1}$ and Lisa F. P. Ng ${ }^{1,2,3,4 *}$ \\ ${ }^{1}$ Singapore Immunology Network, Agency for Science, Technology and Research, Singapore, Singapore, ${ }^{2}$ National \\ University of Singapore Graduate School for Integrative Sciences and Engineering, National University of Singapore, \\ Singapore, Singapore, ${ }^{3}$ Department of Biochemistry, Yong Loo Lin School of Medicine, National University of Singapore, \\ Singapore, Singapore, ${ }^{4}$ Institute of Infection and Global Health, University of Liverpool, Liverpool, United Kingdom
}

Chikungunya virus (CHIKV) is an arthropod-borne alphavirus that causes hallmark debilitating polyarthralgia, fever, and rash in patients. T cell-mediated immunity, especially $\mathrm{CD}^{+}{ }^{+} \mathrm{T}$ cells, are known to participate in the pathogenic role of $\mathrm{CHIKV}$ immunopathology. The other $\mathrm{T}$ cell subsets, notably $\mathrm{CD}^{+}, \mathrm{NKT}$, and gamma-delta $(\gamma \delta) \mathrm{T}$ cells, can also contribute to protective immunity, but their effect is not actuated during the natural course of infection. This review serves to consolidate and discuss the multifaceted roles of these $\mathrm{T}$ cell subsets during acute and chronic phases of $\mathrm{CHIKV}$ infection, and highlight gaps in the current literature. Importantly, the unique characteristics of skin-resident memory $T$ cells are outlined to propose novel prophylactic strategies that utilize their properties to provide adequate, lasting protection.

Keywords: chikungunya, $\mathrm{T}$ cells, immunopathology, vaccination, resident-memory $\mathrm{T}$ cells

\section{INTRODUCTION}

Chikungunya virus (CHIKV) belongs to the Togaviridae family and is transmitted to humans by arthropod vectors, primarily the Aedes aegypti and Ae. albopictus mosquitoes within an urban cycle (1). This alphavirus was first isolated from a patient from Tanzania in 1952 (2), but it spread only to few regions before mellowing down to sporadic outbreaks in the next 30 years (3-11). It re-emerged in the last decade, starting from Kenya in $2004(12,13)$. Since then, it has broadened its geographical range to different regions of Africa, the Réunion island, Asia, Europe, and the Americas $(4,12,14,15)$.

CHIKV-infected patients develop chikungunya fever (CHIKF), a febrile illness characterized with acute hallmark polyarthralgia, along with other disease manifestations like fever and maculopapular rash $(3,16,17)$. Symptoms usually manifest after $4-7$ days of incubation period (3). CHIKV infection has been shown by multiple studies to induce robust immune responses. Specifically, the type-I interferon (IFN)-associated pathways (18-21), the recruitment of innate and adaptive immune cells to the site of infection (22), and the development of protective antibodies for virus resolution (23-29), has been shown to contribute significantly to the self-limiting nature of CHIKF. Although CHIKV-induced symptoms usually resolve in patients within 2 weeks (16), $\sim 30-40 \%$ of these patients go on to develop chronic arthritis, which can be due to inefficient viral clearance, or persistent immune response in patients $(3,16,18)$.

Host innate and adaptive immunity have multifaceted roles in CHIKV infection. While innate immunity in response to CHIKV infection has been well-studied $(3,17,30)$, the functions of adaptive components, such as $\mathrm{T}$ cells and their myriad associated roles remain less defined. Recent 
studies have started to show that CHIKV-specific T cells and antibody response play significant roles in antiviral immunity, immunomodulation and pathology in CHIKV infection (24, $28,31,32$ ). A better comprehension of the roles each $\mathrm{T}$ cell subset play during CHIKV infection may aid in understanding how to control disease progression and immune-mediated pathology. This review illustrates the significance of $\mathrm{T}$ cells in the protection and immunopathogenesis of acute and chronic arthritogenic disease. We also provide alternative perspectives on the prophylactic and therapeutic potential of $\mathrm{T}$ cells against CHIKV.

\section{CD8 $^{+}$T CELLS}

$\mathrm{CD}^{+} \mathrm{T}$ cells have contrasting effects on alphavirus infection. In humans, $\mathrm{CD} 8^{+} \mathrm{T}$ cells express $\mathrm{CD} 69, \mathrm{CD} 107 \mathrm{a}$, granzyme $\mathrm{B}$, and perforin during acute CHIKV infection $(17,33,34)$, markers associated with $\mathrm{T}$ cell activation. Studies have identified putative CD8 epitopes within the CHIKV genome in mice and humans (Figure 1) $(35,36)$. Among these antigenic determinants, the non-structural proteins (nsP1-nsP4) contain a multitude of epitopes that can induce a robust immunological response. Only HLA-A24, B7, and B15 were predicted to express CD8 epitopes hidden within the capsid, E1 and E2 proteins (35). Despite the apparent abundance, only three HLA-A*0201 CD8 epitopes in CHIKV $6 \mathrm{~K}$ protein were experimentally validated to trigger CD8 T cell response (37). The paucity of epitope validation highlights the inaccuracy of in silico modeling to predict epitope immunogenicity. Nevertheless, predicted epitopes require further testing to validate the sequences that are presented by different MHCs. Importantly, it remains unclear whether the recognition of CHIKV epitopes by $\mathrm{CD} 8^{+} \mathrm{T}$ cells has a role to play in eliminating virus-infected cells. This knowledge gap is worth investigating and will open up avenues to employ them as mediators in future $\mathrm{CHIKV}$ vaccines.
In mouse models, $\mathrm{CD}^{+} \mathrm{T}$ cell numbers in the joints increased during acute CHIKV infection. However, they do not protect against $\mathrm{CHIKV}$-associated pathologies as mice deficient in $\mathrm{CD}^{+} \mathrm{T}$ cells still developed joint inflammation (31). This observation is in contrast to other findings whereby CD8 T cells play an active role in mediating viral clearance and disease resolution in mouse models of Ross River virus (RRV) (38) and Venezuela Equine Encephalomyelitis virus (VEEV) (39). CHIKV RNA could be detected in the footpad of mice at up to 16 weeks post-challenge, suggesting that chronic CHIKV infection could persist in the footpad (40). Persistent infection indicates that CHIKV epitopes could be continuously presented by antigen-presenting cells (APCs) to $\mathrm{CD} 8^{+} \mathrm{T}$ cells, leading to sustained activation of $\mathrm{T}$ cell receptor. This will eventually cause $\mathrm{CD}^{+} \mathrm{T}$ cell exhaustion and render them incapable of eliminating infected cells $(41,42)$, resulting in perpetual CHIKV infection. Indeed, the lower levels of $\mathrm{CD}^{+} \mathrm{T}$ cells and their decreased expression of activated marker CD69 suggest an exhausted phenotype in chronic CHIKV patients (33). In chronic viral (e.g., LCMV and HIV) and parasitic (e.g., malaria) diseases, persistent infection causes prolonged activation of $\mathrm{CD}^{+} \mathrm{T}$ cells, which eventually drives them to exhaustion and become unresponsive. This condition happens through, mostly but not limited to, the programmed death-1 signaling axis (43-46). The shutdown of exhausted $\mathrm{CD} 8^{+} \mathrm{T}$ cell function allows pathogens to remain established, cascading into a vicious cycle of a further immune shutdown and more persistent infection. Given that CHIKV infection is shown to persist in infected mice and individuals $(34,40)$, the CHIKVspecific $\mathrm{CD}^{+} \mathrm{T}$ cells may become exhausted and become incapable of controlling the infection. Targeting this pathway to reverse the exhaustion in $\mathrm{CD}^{+} \mathrm{T}$ cells has been demonstrated to eliminate chronic malaria infection in a mouse model (47), thus indicating that this is another potential avenue to treat chronic CHIKV infection.

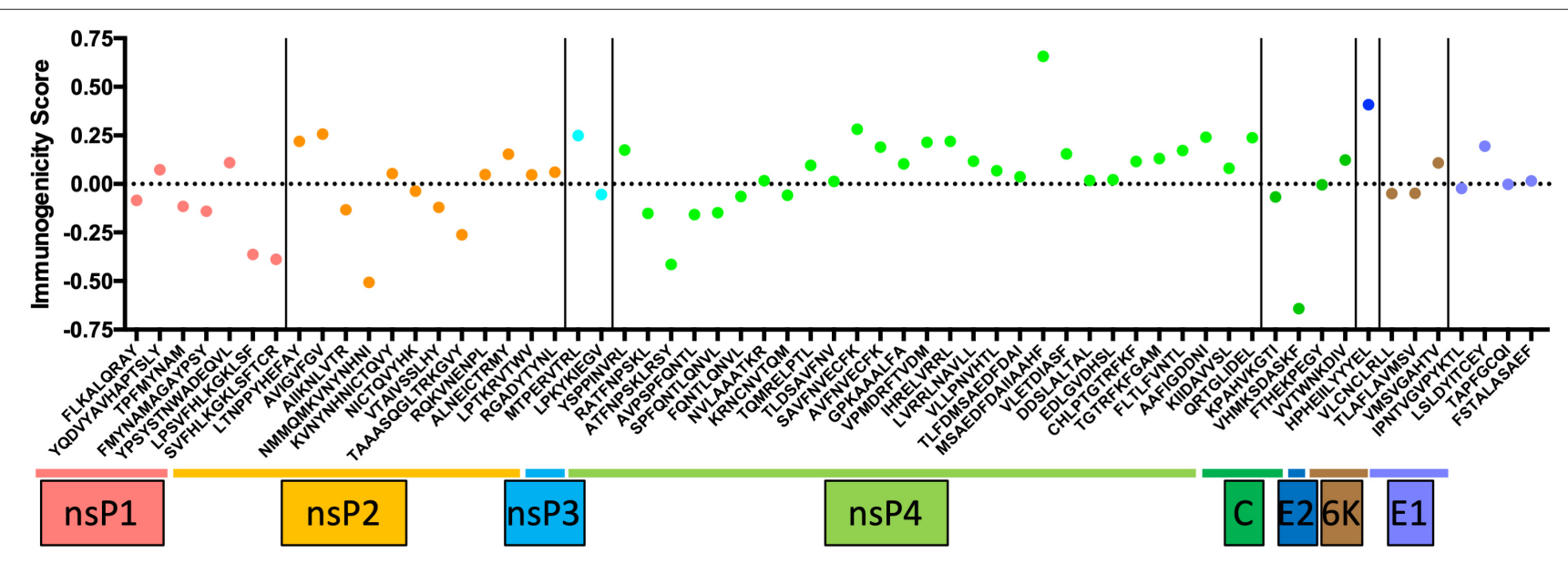

FIGURE 1 | The list of conserved CD8 epitopes in CHIKV that was identified in silico by others and published in the literature were arranged according to the positions they occupy along the CHIKV proteome. The immunogenicity scores are determined through the Immune Epitope Database (IEDB) and plotted as shown. Of all the CD8 epitopes, only the three epitopes in the $6 \mathrm{~K}$ region are experimentally validated. 


\section{CD4 ${ }^{+}$T CELLS}

Activated $\mathrm{CD} 4^{+} \mathrm{T}$ cells have been well-documented to play an essential role in the pathogenesis of CHIKV-induced joint swelling $(31,34,48)$. Our laboratory has comprehensively proven this through multiple methods. Mice depleted of $\mathrm{CD}^{+} \mathrm{T}$ cells do not develop joint pathology when challenged with CHIKV. Concordantly, the use of fingolimod, which blocks lymphocytes from exiting the lymphoid organs, also reduces joint pathology in CHIKV infected mice. In addition, $\mathrm{TCR}^{-1-}$ mice, which lack $\mathrm{T}$ cells, do not develop joint swelling when challenged (32). Independently, another group showed that the administration of antibodies against CTLA-4, which binds to CTLA-4 receptors found on the cell surface of activated $\mathrm{CD} 4^{+} \mathrm{T}$ cells, caused elimination of the latter and thereby reduced joint swelling in CHIKV-infected mice (49). Currently, there is no mouse model that develops the chronic arthralgia and arthritis as seen in chronic patients. Thus, it remains to be seen if the activated $\mathrm{CD} 4^{+} \mathrm{T}$ cells are also responsible for the chronic phase of CHIKV infection.

Pathogenic CHIKV-specific CD4 ${ }^{+}$T cells in CHIKV mouse models express T-bet and secrete IFN- $\gamma$, markers that are associated with Th1 phenotype (50). These findings concur with another study, which shows higher levels of Th1associated cytokines in the sera of CHIKV-infected patients (34). Although this drives IFN- $\gamma$ production during infection, the antiviral effects of IFN- $\gamma$ are unable to block CHIKV replication in virus-infected cells due to CHIKV interference with downstream JAK-STAT signaling (51). These $\mathrm{CD}^{+} \mathrm{T}$ cells, together with $\mathrm{CD}^{+} \mathrm{T}$ cells, is detected in the joints of patients during the chronic phase of CHIKV infection (34). Two CHIKV CD4 ${ }^{+}$epitopes have been identified in mouse models thus far, with the cognate $\mathrm{CD}^{+} \mathrm{T}$ cells expressing IFN- $\gamma$ during CHIKV infection (32). Despite CD4 ${ }^{+}$ $\mathrm{T}$ cells being a cause of the pathogenic swelling accompanying CHIKV infection, they are also crucial in orchestrating the formation of CHIKV-specific antibody response. Dominant CHIKV-specific antibodies are of the isotype $\operatorname{IgG} 2 \mathrm{c}(19,28)$, and their production was severely impaired when $\mathrm{CD} 4 \mathrm{~T}$ cells were absent (28).

\section{REGULATORY T CELLS}

Among the heterogeneous $\mathrm{CD} 4^{+} \mathrm{T}$ cell population, regulatory $\mathrm{T}$ cells (Tregs) can also contribute to the protection against CHIKV. Tregs are able to interact with APCs in the peripheral lymph nodes and bring about downregulation of costimulatory molecules in the latter (52). Thus, when the APCs present CHIKV epitopes to $\mathrm{CD} 4^{+} \mathrm{T}$ cells, they become anergic instead and do not proliferate or migrate to the infected joints to cause joint swelling. However, the viral load in virus-infected mice was not affected by Tregs (52). Patients with acute and chronic CHIKV infections were shown to have lower levels of Treg, while recovered patients display Treg levels that are comparable to healthy controls (53). This finding concurs with the data from murine models, suggesting that Tregs prevent hyperactivation of pathogenic $\mathrm{CD} 4^{+} \mathrm{T}$ cells, thereby controlling joint pathology.

\section{NATURAL KILLER T CELLS}

The impact of natural killer T (NKT) cells in CHIKV infection is less well-understood. In patients, acute CHIKV infection resulted in an increase of NKT cells in the blood (54). These NKT cells were found to upregulate the expression of IFN- $\gamma$, but not perforin. Although PBMCs from acute samples induced cytotoxicity in K562 cells during co-culture, it remains unclear if NKT cells account for the majority of the cytotoxicity effect (54). In chronic patients, NKT cell levels were significantly lower than healthy controls (55), although they still upregulated IFN- $\gamma$ expression. In contrast, the expression levels of IFN- $\gamma$ and TNF$\alpha$ by NKT cells in convalescent patients are similar to that of healthy controls $(54,55)$.

In mice, levels of IFN- $\gamma$-expressing NKT cell remain unchanged in CHIKV-infected mice, as compared to healthy controls (48). However, these cells accumulate in the spleens of mice that are co-infected with CHIKV and malaria parasites (48). This event is due to the increased expression of chemokines CXCL9 and CXCL10 in the spleens, which attract and retain lymphocytes that express cognate chemokine receptors. Since mouse and human NKT cells express CXCR3 (which recognizes CXCL9 and CXCL10), these cells are likely to be trapped in the spleen, preventing them from migrating to the peripheral joints (56-58). Although this strategy of lymphocyte sequestration leads to decreased CHIKV immunopathology $(32,49)$, it is not clear how much does NKT cells contribute to this amelioration.

\section{GAMMA-DELTA $(\gamma \delta)$ T CELLS}

Gamma-delta $\mathrm{T}$ cells are reported to play a protective role against CHIKV infection (59). These cells do not affect CHIKV virus replication in the joints. Instead, their absence is associated with increased joint swelling and tissue damage in the infected mice. The absence of $\gamma \delta \mathrm{T}$ cells were also linked to increased monocyte infiltration to the joints and increased levels of pro-inflammatory mediators CCL2, CXCL9, and IFN- $\gamma$ (59). Hence, the resulting pro-inflammatory milleu leads to more inflammatory cell infiltration and result in tissue damage that is observed during CHIKV infection. However, there is no information on the role of $\gamma \delta \mathrm{T}$ cells in CHIKV patients. Thus, the extent of protection these cells offer in human settings remains unclear.

\section{MOBILIZING T CELLS AGAINST CHIKV IN VACCINE DESIGN}

The roles that each subset of $\mathrm{T}$ cells play in the joint swelling during CHIKV infection is illustrated in Figure 2. Despite their participation in CHIKV immunopathology, they have the potential to be included as mediators of effective antiCHIKV vaccine strategies. Although researchers have been investigating experimental vaccines against CHIKV, most of these still rely on antibodies to neutralize the viruses (23, 28, 60-63). Furthermore, some of the CHIKV vaccines have been demonstrated to protect against other alphaviruses, such 


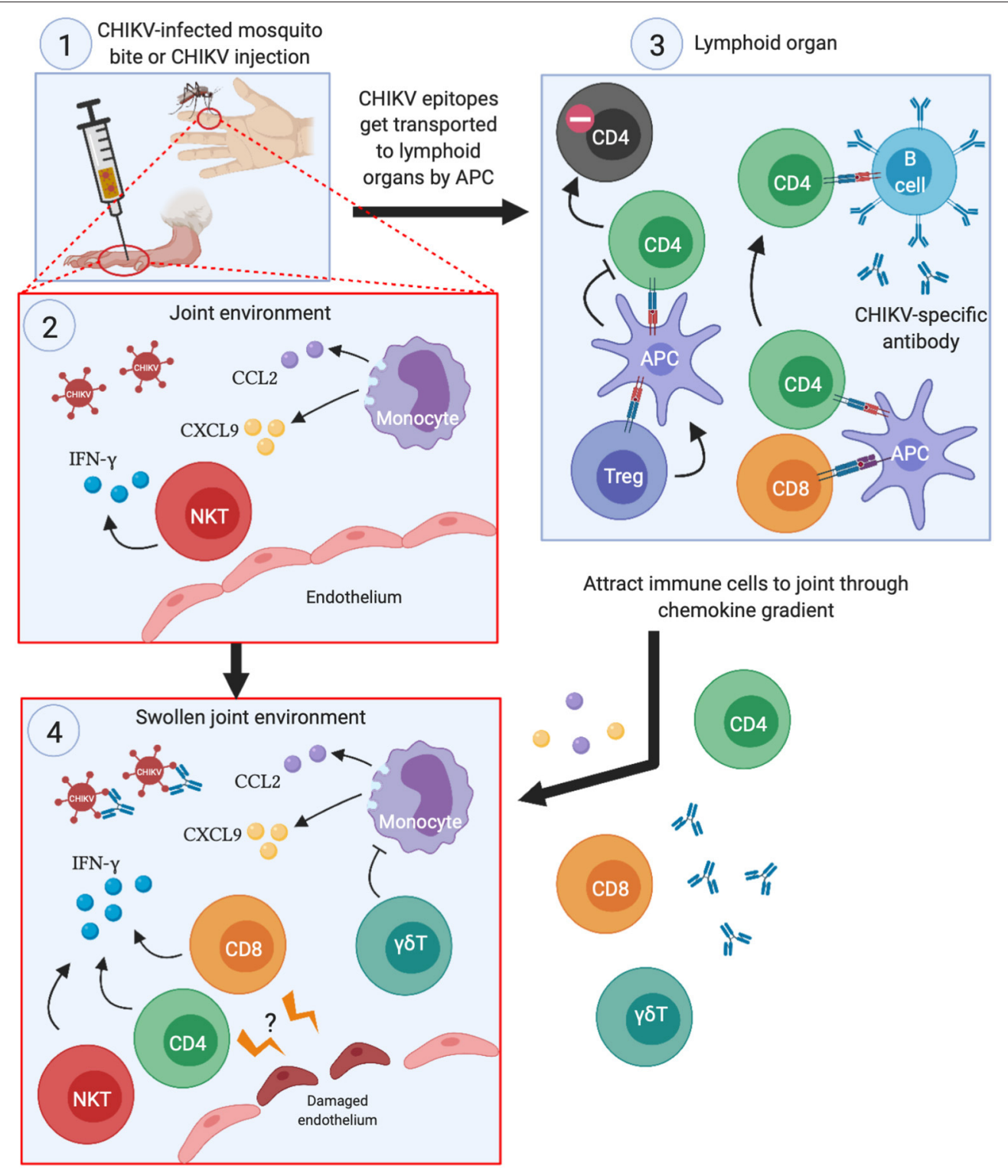

FIGURE 2 | Summary of the roles each T cell subset play during acute CHIKV infection. (1) When CHIKV-infected mosquitoes transmit the virus to its human host (or experimental infection in mice), CHIKV infects the surrounding cells and creates pro-inflammatory milleu in the joints. (2) This serves to attract monocytes and NKT cells to the joints, which exacerbates the inflammation by secreting pro-inflammatory cytokines and chemokines, thereby potentiating the chemoattraction of other immune cells to the infection site. (3) The APCs that engulfs CHIKV antigens travel to lymphoid organs, present CHIKV epitopes to CD4 and CD8 T cells and activate them. Activated CD4 T cells then trigger CHIKV-specific B cells to develop antibodies that can neutralize the virus. Treg cells may also interact with APCs that ultimately lead to anergy in CHIKV-specific CD4 T cells. (4) Proliferating CD4 and CD8 T cells migrate to the swollen joints and contribute to the inflammation through IFN- $\gamma$ secretion. Although not directly demonstrated, CHIKV-specific CD4 and CD8T cells may recognize infected endothelial cells at the site of infection, leading to disruption of the barrier and worsens joint swelling.

as RRV (19) and O'nyong'nyong virus (ONNV) (23). In the RRV challenge study, the lowest effective dose $(0.1 \mu \mathrm{g}$ virus $)$ that conferred complete protection (denoted as the absence of viremia) did not increase the antibody response against CHIKV. Full protection only happens when the authors increased the dosage to $10 \mu \mathrm{g}$ (19). This observation suggests that $\mathrm{T}$ cells may be instrumental in conferring protection at the lower doses. However, vaccination with recombinant baculovirus expressing
CHIKV envelope proteins caused aged mice ( $>18$ months old) to become more susceptible to CHIKV infection (62), which was partly explained by the lower antibody titers in the aged mice. Although antigenic variations among $\mathrm{CHIKV}$ isolates are not prevalent currently, subtle changes in the CHIKV proteome was demonstrated to affect the neutralizing effect of pre-existing anti-CHIKV antibodies $(26,64,65)$. Thus, any mutation that results in reproductive-competent virus and yet 
abolishes antibody binding to CHIKV epitopes may result in future pandemic outbreaks.

\section{UTILIZING SKIN RESIDENT MEMORY T CELLS TO CONFER PAN-ALPHAVIRUS IMMUNITY}

The notion of inducing CHIKV-specific memory $\mathrm{T}$ cells as mediators of protection is attractive as $\mathrm{T}$ cell epitopes are generally better conserved than $\mathrm{B}$ cell antigens, mitigating the risk of immune escape through antigenic variations (66-69). Of the memory $\mathrm{T}$ cells, tissue-resident memory $\mathrm{T}$ cells (TRMs) are a unique subset of cells that is distinct from conventional memory $\mathrm{T}$ cells, in that the former dwell at the peripheral organs (70-73). The latter either reside in the lymphoid organs (central memory $\mathrm{T}$ cells) or recirculate in the body (effector memory $\mathrm{T}$ cells) $(74,75)$. Thus, TRMs could function as adaptive immune cells that act as first-line responders at the site of infection $(71,73,76)$. Putative CHIKV-specific skin TRMs can be well-positioned to react to CHIKV-infected cells at the feeding site by virus-infected mosquitos during a blood meal.

Establishment of TRMs in the skin begins when clonally expanded $\mathrm{T}$ cells migrate from lymphoid organs to the skin. Some of these skin-homing $\mathrm{T}$ cells remain in place and develop into skin TRMs $(77,78)$. Vaccination leads to the widespread establishment of TRMs throughout the body, not only at the vaccination site (78). Thus, it is highly plausible that one can generate CHIKV-specific skin TRMs through vaccination at the skin. Interestingly, effector $\mathrm{T}$ cells were reported to migrate to all parts of the skin instead of accumulating only at the site of the infection or vaccination $(79,80)$. This phenomenon occurs due to the presence of E-selectin, ICAM-1 and other chemokines that are expressed by post-capillary venules at low levels throughout the skin (81). Hence, the resulting skin TRMs generated can protect against CHIKV infection from anywhere, regardless of where the virus-infected mosquitoes choose to probe and release the virus into the host.

In the event where CHIKV penetrates the skin barrier and infect the surrounding cells during blood feeding by mosquitoes, CHIKV-specific skin resident memory $\mathrm{T}$ cells can recognize virus-infected cells quickly. This identification leads to rapid coordination of the anti-CHIKV immune responses and leads to the elimination of virus-infected cells before the disease is established $(82,83)$. Moreover, CHIKV exposure should further boost pre-existing anti-CHIKV immune response and lead to the accumulation of more CHIKV-specific skin resident memory $\mathrm{T}$ cells $(79,80)$. Over time, repeated exposure of CHIKV should lead to further CHIKV-specific skin TRM accumulation all over the skin, with no establishment of CHIKV pathology.

\section{REFERENCES}

1. Strauss J, Strauss E. The alphaviruses: gene expression, replication, and evolution. Microbiol Rev. (1994) 58:491-562. doi: 10.1128/MMBR.58.3.491-562.1994
The geographical range of mosquitoes that transmit the alphaviruses is projected to increase in the future due to climate change (84). Moreover, CHIKV shares some homology with other alphaviruses with the potential to cause unprecedented outbreaks (85-89). This shift may ultimately lead to the spread of CHIKV and other alphaviruses and cause future epidemics. However, as depicted by Roundy et al. (90) and Powers et al. (91), the close homology between CHIKV and other viruses within the family of alphaviruses suggest that they may share conserved epitopes that can induce $\mathrm{T}$ cell responses. Hence, some of the CHIKV-specific memory $\mathrm{T}$ cells can have the potential to target other alphaviruses and eliminate them. This knowledge may lead to the development of pan-alphavirus vaccines that are effective in preventing sudden alphavirus outbreaks, such as the spike in deaths from Eastern Equine Encephalomyelitis Virus (EEEV) in the United States in 2019, which is becoming endemic in the United States (92).

\section{CONCLUDING REMARKS}

The re-emergence of CHIKV underscores the need for effective vaccine strategies to prevent further global CHIKV dissemination. In immunological naïve individuals, CHIKV infection puts them at risk of having their immune system manipulated toward CHIKV pathology and virus persistence. An optimal vaccine against CHIKV invokes not only humoral response, but more importantly, localized CHIKV-specific, cell-mediated immunity at the skin, and yet avoids the induction of CHIKV-mediated immunopathology that is associated with pathogenic CD4 T cells. By inducing anti-CHIKV TRMs at the skin before infection strikes, they can rapidly clear the virus before it disseminates and triggers the associated immunopathology. Besides, anti-CHIKV TRMs have the potential to react to more conserved CHIKV epitopes (which may also be conserved in closely related alphaviruses) and the immunity buildup increases with each natural infection, providing a robust, potent immunity against CHIKV, and possibly other alphaviruses.

\section{AUTHOR CONTRIBUTIONS}

All authors listed have made a substantial, direct and intellectual contribution to the work, and approved it for publication.

\section{FUNDING}

This study was funded by SIgN, Agency for Science, Technology and Research (A*STAR) core grant (Grant number F00018).

2. Lumsden W. An epidemic of virus disease in Southern Province, Tanganyika territory, in 1952-1953 II. general description and epidemiology. T Roy Soc Trop Med H. (1955) 49:33-57. doi: 10.1016/0035-9203(55)90081-X

3. Schwartz O, Albert ML. Biology and pathogenesis of chikungunya virus. Nat Rev Microbiol. (2010) 8:491-500. doi: 10.1038/nrmicro2368 
4. Staples EJ, Breiman RF, Powers AM. Chikungunya fever: an epidemiological review of a re-emerging infectious disease. Clin Infect Dis. (2009) 49:942-8. doi: $10.1086 / 605496$

5. Nimmannitya S, Halstead S, Cohen S, Margiotta M. Dengue and chikungunya virus infection in man in Thailand, 1962-1964. I. observations on hospitalized patients with hemorrhagic fever. Am J Trop Med Hygiene. (1969) 18:954-71. doi: 10.4269/ajtmh.1969.18.954

6. Thaikruea L, Charearnsook O, Reanphumkarnkit S, Dissomboon P, Phonjan $\mathrm{R}$, Ratchbud S, et al. Chikungunya in Thailand: a re-emerging disease? Southeast Asian J Trop Med Pub Health. (1997) 28:359-64.

7. Padbidri V, Gnaneswar T. Epidemiological investigations of chikungunya epidemic at Barsi, Maharashtra state, India. J Hygiene Epidemiol Microbiol Immunol. (1979) 23:445-51.

8. Mendis N. Epidemiology of dengue-like fever in Ceylon. Ceylon Med J. (1967) 12:67-74

9. Munasinghe D, Amarasekera P, Fernando C. An epidemic of dengue-like fever in Ceylon (chikungunya-a clinical and haematological study. Ceylon Med J. (1966) 11:129-42.

10. Retuya T, Ting D, Dacula B, Lanada J, Jr RV, Hugo C, Ogayon J, et al. Chikungunya fever outbreak in an agricultural village in Indang, Cavite, Philippines. Phillipp J Microbiol Infect Dis. (1998) 27:93-6.

11. Thein S, Linn LM, Aaskov J, Aung M, Aye M, Zaw A, et al. Development of a simple indirect enzyme-linked immunosorbent assay for the detection of immunoglobulin $\mathrm{M}$ antibody in serum from patients following an outbreak of chikungunya virus infection in Yangon, Myanmar. Trans R Soc Trop Med Hygiene. (1992) 86:438-42. doi: 10.1016/0035-9203(92)90260-J

12. Sergon K, Njuguna C, Kalani R, Ofula V, Onyango C, Konongoi LS, et al. Seroprevalence of chikungunya virus (CHIKV) infection on Lamu Island, Kenya, October 2004. Am J Trop Med Hyg. (2008) 78:333-7. doi: 10.4269/ajtmh.2008.78.333

13. Coffey LL, Failloux A-B, Weaver SC. Chikungunya virus-vector interactions. Viruses. (2014) 6:4628-63. doi: 10.3390/v6114628

14. Powers A, Logue C. Changing patterns of chikungunya virus: reemergence of a zoonotic arbovirus. J Gene Virol. (2007) 88:2363-77. doi: 10.1099/vir.0.82858-0

15. Khan K, Bogoch I, Brownstein JS, Miniota J, Nicolucci A, Hu W, et al. Assessing the origin of and potential for international spread of chikungunya virus from the caribbean. PLoS Curr. (2014) 6, 1-15. doi: 10.1371/currents.outbreaks.2134a0a7bf37fd8d388181539fea2da5

16. Kam Y-W, Ong EK, Rénia L, Tong J-C, Ng LF. Immuno-biology of chikungunya and implications for disease intervention. Microbes Infect Institut Pasteur. (2009) 11:1186-96. doi: 10.1016/j.micinf.2009.09.003

17. Wauquier N, Becquart P, Nkoghe D, Padilla C, Ndjoyi-Mbiguino A, Leroy EM. The acute phase of chikungunya virus infection in humans is associated with strong innate immunity and T CD8 cell activation. J Infect Dis. (2010) 204:115-23. doi: 10.1093/infdis/jiq006

18. Chow A, Her Z, Ong EK, Chen J, Dimatatac F, Kwek DJ, et al. Persistent arthralgia induced by chikungunya virus infection is associated with interleukin-6 and granulocyte macrophage colony-stimulating factor. J Infect Dis. (2011) 203:149-57. doi: 10.1093/infdis/jiq042

19. Gardner J, Anraku I, Le TT, Larcher T, Major L, Roques P, et al. Chikungunya virus arthritis in adult wild-type mice. J Virol. (2010) 84:802132. doi: 10.1128/JVI.02603-09

20. Labadie K, Larcher T, Joubert C, Mannioui A, Delache B, Brochard P, et al. Chikungunya disease in nonhuman primates involves long-term viral persistence in macrophages. J Clin Investig. (2010) 120:894-906. doi: 10.1172/JCI40104

21. Schilte C, Couderc T, Chretien F, Sourisseau M, Gangneux N, GuivelBenhassine F, et al. Type I IFN controls chikungunya virus via its action on nonhematopoietic cells. J Exp Med. (2010) 207:429-42. doi: 10.1084/jem.20090851

22. Lum F, Ng LF. Cellular and molecular mechanisms of chikungunya pathogenesis. Antiviral Res. (2015) 120:165-74. doi: 10.1016/j.antiviral.2015.06.009

23. Chan YH, Teo TH, Utt A, Tan JJ, Amrun SN, Abu Bakar F, et al. Mutating chikungunya virus non-structural protein produces potent live-attenuated vaccine candidate. EMBO Mol Med. (2019) 11:e10092. doi: $10.15252 / \mathrm{emmm} .201810092$
24. Kam YW, Simarmata D, Chow A, Her Z, Teng TS, Ong EK, et al. Early appearance of neutralizing immunoglobulin G3 antibodies is associated with chikungunya virus clearance and long-term clinical protection. J Infect Dis. (2012) 205:1147-54. doi: 10.1093/infdis/jis033

25. Kam Y-W, Lum F, Teo T, Lee WW, Simarmata D, Harjanto S, et al. Early neutralizing IgG response to chikungunya virus in infected patients targets a dominant linear epitope on the E2 glycoprotein. EMBO Mol Med. (2012) 4:330-43. doi: 10.1002/emmm.201200213

26. Kam Y-W, Lee WW, Simarmata D, Harjanto S, Teng T-S, Tolou H, et al. Longitudinal analysis of the human antibody response to chikungunya virus infection: implications for serodiagnosis and vaccine development. J Virol. (2012) 86:13005-15. doi: 10.1128/JVI.01780-12

27. Kam Y-W, Lee WW, Simarmata D, Grand R, Tolou H, Merits A, et al. Unique epitopes recognized by antibodies induced in chikungunya virus-infected non-human primates: implications for the study of immunopathology and vaccine development. PLoS ONE. (2014) 9:e95647. doi: 10.1371/journal.pone.0095647

28. Lum F, Teo T, Lee WW, Kam Y-W, Rénia L, Ng LF. An essential role of antibodies in the control of chikungunya virus infection. J Immunol. (2013) 190:6295-302. doi: 10.4049/jimmunol.1300304

29. Poo Y, Nakaya H, Gardner J, Larcher T, Schroder WA, Le TT, et al. Diamond. CCR2 deficiency promotes exacerbated chronic erosive neutrophil-dominated chikungunya virus arthritis. J Virol. (2014) 88:6862-72. doi: 10.1128/JVI.03364-13

30. Petitdemange C, Wauquier N, Vieillard V. Control of immunopathology during chikungunya virus infection. J Allergy Clin Immunol. (2015) 135:84655. doi: 10.1016/j.jaci.2015.01.039

31. Teo T, Lum F, Claser C, Lulla V, Lulla A, Merits A, et al. A pathogenic role for $\mathrm{CD}^{+} \mathrm{T}$ cells during chikungunya virus infection in mice. J Immunol. (2013) 190:259-69. doi: 10.4049/jimmunol.1202177

32. Teo T, Chan Y-H, Lee WW, Lum F, Amrun S, Her Z, et al. Fingolimod treatment abrogates chikungunya virus-induced arthralgia. Sci Transl Med. (2017) 9:eaal1333. doi: 10.1126/scitranslmed.aal1333

33. de Dias C, Gois B, Lima V, Guerra-Gomes I, Araújo J, de Gomes J, et al. Human CD8 T-cell activation in acute and chronic chikungunya infection. Immunology. (2018) 155:499-504. doi: 10.1111/imm.12992

34. Hoarau J-J, Bandjee M-C, Trotot P, Das T, Li-Pat-Yuen G, Dassa B, et al. Persistent chronic inflammation and infection by chikungunya arthritogenic alphavirus in spite of a robust host immune response. J Immunol. (2010) 184:5914-27. doi: 10.4049/jimmunol.0900255

35. Pratheek B, Suryawanshi AR, Chattopadhyay S, Chattopadhyay S. In silico analysis of MHC-I restricted epitopes of chikungunya virus proteins: implication in understanding anti-CHIKV $\mathrm{CD}^{+} \mathrm{T}$ cell response and advancement of epitope based immunotherapy for CHIKV infection. Infect Gene Evol. (2015) 31:118-26. doi: 10.1016/j.meegid.2015.01.017

36. Waheed Y, Safi S, Najmi M, Aziz H, Imran M. Prediction of promiscuous T cell epitopes in RNA dependent RNA polymerase of chikungunya virus. Asian Pacific J Trop Med. (2017) 10:760-4. doi: 10.1016/j.apjtm.2017.07.023

37. Lorente E, Barriga A, García-Arriaza J, Lemonnier FA, Esteban M, López D. Complex antigen presentation pathway for an HLA-A*0201-restricted epitope from chikungunya 6K protein. PLoS Negl Trop Dis. (2017) 11:e0006036. doi: 10.1371/journal.pntd.0006036

38. Burrack KS, Montgomery SA, Homann D, Morrison TE. CD ${ }^{+}$T Cells control ross river virus infection in musculoskeletal tissues of infected mice. $J$ Immunol. (2015) 194:678-89. doi: 10.4049/jimmunol.1401833

39. Brooke CB, Deming DJ, Whitmore AC, White LJ, Johnston RE. T cells facilitate recovery from venezuelan equine encephalitis virus-induced encephalomyelitis in the absence of antibody. J Virol. (2010) 84:4556-68. doi: 10.1128/JVI.02545-09

40. Hawman DW, Stoermer KA, Montgomery SA, Pal P, Oko L, Diamond MS, et al. Chronic joint disease caused by persistent chikungunya virus infection is controlled by the adaptive immune response. J Virol. (2013) 87:13878-88. doi: 10.1128/JVI.02666-13

41. Mueller SN, Ahmed R. High antigen levels are the cause of T cell exhaustion during chronic viral infection. Proc Natl Acad Sci USA. (2009) 106:8623-8. doi: 10.1073/pnas.0809818106

42. Hashimoto M, Kamphorst AO, Im S, Kissick HT, Pillai RN, Ramalingam $\mathrm{SS}$, et al. CD8 $\mathrm{T}$ cell exhaustion in chronic infection and cancer: 
opportunities for interventions. Ann Rev Med. (2018) 69:301-18. doi: 10.1146/annurev-med-012017-043208

43. Blackburn SD, Shin H, Haining NW, Zou T, Workman CJ, Polley A, et al. Coregulation of $\mathrm{CD}^{+} \mathrm{T}$ cell exhaustion by multiple inhibitory receptors during chronic viral infection. Nat Immunol. (2008) 10:29-37. doi: $10.1038 /$ ni.1679

44. Butler NS, Moebius J, Pewe LL, Traore B, Doumbo OK, Tygrett LT, et al. Therapeutic blockade of PD-L1 and LAG-3 rapidly clears established blood-stage plasmodium infection. Nat Publ Group. (2012) 13:188-95. doi: $10.1038 /$ ni.2180

45. Karunarathne DS, Horne-Debets JM, Huang JX, Faleiro R, Leow C, Amante F, et al. Programmed death-1 ligand 2-mediated regulation of the PD-L1 to PD1 axis is essential for establishing $\mathrm{CD}^{+} \mathrm{T}$ cell immunity. Immunity. (2016) 45:333-45. doi: 10.1016/j.immuni.2016.07.017

46. Horne-Debets JM, Faleiro R, Karunarathne DS, Liu XQ, Lineburg KE, Poh C, et al. PD-1 Dependent exhaustion of $\mathrm{CD}^{+}{ }^{+} \mathrm{T}$ cells drives chronic malaria. Cell Rep. (2013) 5:1204-13. doi: 10.1016/j.celrep.2013.11.002

47. Horne-Debets JM, Karunarathne DS, Faleiro RJ, Poh C, Rénia L, Wykes MN. Mice lacking programmed cell death-1 show a role for $\mathrm{CD} 8(+) \mathrm{T}$ cells in long-term immunity against blood-stage malaria. Sci Rep. (2016) 6:26210. doi: $10.1038 /$ srep 26210

48. Teo T, Howland SW, Claser C, Gun S, Poh C, Lee WW, et al. Co-infection with chikungunya virus alters trafficking of pathogenic $\mathrm{CD} 8^{+} \mathrm{T}$ cells into the brain and prevents plasmodium-induced neuropathology. EMBO Mol Med. (2018) 10:121-38. doi: $10.15252 / \mathrm{emmm} .201707885$

49. Miner JJ, Cook LE, Hong JP, ith A, Richner JM, imak R, et al. Therapy with CTLA4-Ig and an antiviral monoclonal antibody controls chikungunya virus arthritis. Sci Transl Med. (2017) 9:eaah3438. doi: $10.1126 /$ scitranslmed.aah3438

50. Carissimo G, Teo T, Chan Y-H, Lee C, Lee B, Torres-Ruesta A, et al. Viperin controls chikungunya virus-specific pathogenic T cell IFN $\gamma$ Th1 stimulation in mice. Life Sci Alliance. (2019) 2:e201900298. doi: 10.26508/lsa.2019 00298

51. Fros JJ, Liu W, Prow NA, Geertsema C, Ligtenberg M, Vanlandingham DL, et al. Chikungunya virus nonstructural protein 2 inhibits type I/II interferon-stimulated JAK-STAT signaling. J Virol. (2010) 84:10877-87. doi: 10.1128/JVI.00949-10

52. Lee WW, Teo T, Her Z, Lum F, Kam Y-W, Haase D, et al. Expanding regulatory $\mathrm{T}$ cells alleviates chikungunya virus-induced pathology in mice. J Virol. (2015) 89:7893-904. doi: 10.1128/JVI.00998-15

53. Kulkarni S, Ganu M, Jayawant P, Thanapati S, Ganu A, Tripathy A. Regulatory T cells and IL-10 as modulators of chikungunya disease outcome: a preliminary study. Eur J Clin Microbiol Infect Dis. (2017) 36:1-7. doi: $10.1007 /$ s10096-017-3087-4

54. Thanapati S, Das R, Tripathy AS. Phenotypic and functional analyses of NK and NKT-like populations during the early stages of chikungunya infection. Front Microbiol. (2015) 6:23. doi: 10.3389/fmicb.2015.00895

55. Thanapati S, Ganu MA, Tripathy AS. Differential inhibitory and activating NK cell receptor levels and NK/NKT-like cell functionality in chronic and recovered stages of chikungunya. PLoS ONE. (2017) 12:e0188342. doi: 10.1371/journal.pone.0188342

56. Wingender G, Stepniak D, Krebs P, Lin L, McBride S, Wei B, et al. Intestinal microbes affect phenotypes and functions of invariant natural killer $\mathrm{T}$ cells in mice. Gastroenterology. (2012) 143:418-28. doi: 10.1053/j.gastro.2012. 04.017

57. Johnston B, Kim CH, Soler D, Emoto M, Butcher EC. Differential chemokine responses and homing patterns of murine TCR $\alpha \beta$ NKT cell subsets. $J$ Immunol. (2003) 171:2960-69. doi: 10.4049/jimmunol.171.6.2960

58. Kim CH, Johnston B, Butcher EC. Trafficking machinery of NKT cells: shared and differential chemokine receptor expression among $\mathrm{V} \alpha 24^{+} \mathrm{V} \beta 11^{+} \mathrm{NKT}$ cell subsets with distinct cytokine-producing capacity. Blood. (2002) 100:11-6. doi: 10.1182/blood-2001-12-0196

59. Long KM, Ferris MT, Whitmore AC, Montgomery SA, Thurlow LR, McGee $\mathrm{CE}$, et al. $\gamma \delta \mathrm{T}$ cells play a protective role in chikungunya virus-induced disease. J Virol. (2016) 90:433-43. doi: 10.1128/JVI.02159-15

60. Hallengärd D, Lum F, Kümmerer BM, Lulla A, Lulla V, García-Arriaza J, et al. Prime-boost immunization strategies against chikungunya virus. J Virol. (2014) 88:13333-43. doi: 10.1128/JVI.01926-14
61. Weger-Lucarelli J, Chu H, Aliota MT, Partidos CD, Osorio JE. A novel MVA vectored chikungunya virus vaccine elicits protective immunity in mice. PLoS Negl Trop Dis. (2014) 8:e2970. doi: 10.1371/journal.pntd.0002970

62. Arévalo MT, Huang Y, Jones CA, Ross TM. Vaccination with a chikungunya virus-like particle vaccine exacerbates disease in aged mice. PLoS Negl Trop Dis. (2019) 13:e0007316. doi: 10.1371/journal.pntd.0007316

63. Reisinger EC, Tschismarov R, Beubler E, Wiedermann U, Firbas C, Loebermann $\mathrm{M}$, et al. Immunogenicity, safety, and tolerability of the measles-vectored chikungunya virus vaccine MV-CHIK: a double-blind, randomised, placebo-controlled and active-controlled phase 2 trial. Lancet. (2018) 392:2718-27. doi: 10.1016/S0140-6736(18)32488-7

64. Chua C-L, Sam I-C, Merits A, Chan Y-F. Antigenic variation of East/Central/South African and Asian chikungunya virus genotypes in neutralization by immune sera. PLoS Negl Trop Dis. (2016) 10:e0004960. doi: 10.1371/journal.pntd.0004960

65. Gorchakov R, Wang E, Leal G, Forrester NL, Plante K, Rossi SL, et al. Attenuation of chikungunya virus vaccine strain 181/clone 25 is determined by two amino acid substitutions in the e2 envelope glycoprotein. J Virol. (2012) 86:6084-96. doi: 10.1128/JVI.06449-11

66. Johnson PL, Kochin BF, Ahmed R, Antia R. How do antigenically varying pathogens avoid cross-reactive responses to invariant antigens? Proc $R$ Soc $B$ Biol Sci. (2012) 279:2777-85. doi: 10.1098/rspb.2012.0005

67. Deitsch KW, Lukehart SA, Stringer JR. Common strategies for antigenic variation by bacterial, fungal and protozoan pathogens. Nat Rev Microbiol. (2009) 7:493-503. doi: 10.1038/nrmicro2145

68. Westernberg L, Schulten V, Greenbaum JA, Natali S, Tripple V, McKinney $\mathrm{DM}$, et al. T-cell epitope conservation across allergen species is a major determinant of immunogenicity. J Allergy Clin Immunol. (2016) 138:571-8.e7. doi: 10.1016/j.jaci.2015.11.034

69. Li Z-R, Zarnitsyna VI, Lowen AC, Weissman D, Koelle K, Kohlmeier JE, et al. Why are CD8 T cell epitopes of human influenza a virus conserved? J Virol. (2019) 93:e01534-18. doi: 10.1128/JVI.01534-18

70. Shin H, Iwasaki A. Tissue-resident memory T cells. Immunol Rev. (2013) 255:165-81. doi: 10.1111/imr.12087

71. Mueller SN, Mackay LK. Tissue-resident memory T cells: local specialists in immune defence. Nat Rev Immunol. (2016) 16:79-89. doi: 10.1038/nri.2015.3

72. Cauley L, Lefrançois L. Guarding the perimeter: protection of the mucosa by tissue-resident memory T cells. Mucosal Immunol. (2013) 6:14-23. doi: $10.1038 / \mathrm{mi} .2012 .96$

73. Park C, Kupper TS. The emerging role of resident memory $\mathrm{T}$ cells in protective immunity and inflammatory disease. Nat Med. (2015) 21:688-97. doi: $10.1038 / \mathrm{nm} .3883$

74. Mueller SN, Gebhardt T, Carbone FR, Heath WR. Memory T cell subsets, migration patterns, and tissue residence. Ann Rev Immunol. (2013) 31:137-61. doi: 10.1146/annurev-immunol-032712-095954

75. Lauvau G, Boutet M, Williams TM, Chin S, Chorro L. Memory CD8(+) T Cells: innate-like sensors and orchestrators of protection. Trends Immunol. (2016) 37:375-85. doi: 10.1016/j.it.2016.04.001

76. Shin $H$, Iwasaki A. A vaccine strategy that protects against genital herpes by establishing local memory T cells. Nature. (2012) 491:463-7. doi: 10.1038/nature11522

77. Davies B, Prier JE, Jones CM, Gebhardt T, Carbone FR, Mackay LK. Cutting edge: tissue-resident memory $\mathrm{T}$ Cells generated by multiple immunizations or localized deposition provide enhanced immunity. J Immunol. (2017) 198:2233-7. doi: 10.4049/jimmunol.1601367

78. Gálvez-Cancino F, López E, Menares E, Díaz X, Flores C, Cáceres P, et al. Vaccination-induced skin-resident memory $\mathrm{CD}^{+} \mathrm{T}$ cells mediate strong protection against cutaneous melanoma. Oncoimmunology. (2018) 7:e1442163. doi: 10.1080/2162402X.2018.1442163

79. Jiang X, Clark RA, Liu L, Wagers AJ, Fuhlbrigge RC, Kupper TS. Skin infection generates non-migratory memory $\mathrm{CD} 8^{+} \mathrm{T}_{\mathrm{RM}}$ cells providing global skin immunity. Nature. (2012) 483:227-31. doi: 10.1038/nature10851

80. Gaide O, Emerson RO, Jiang X, Gulati N, Nizza S, Desmarais C, et al. Common clonal origin of central and resident memory $\mathrm{T}$ cells following skin immunization. Nat Med. (2015) 21:647-53. doi: 10.1038/nm.3860

81. Chong BF, Murphy J-E, Kupper TS, Fuhlbrigge RC. E-selectin, thymus- and activation-regulated chemokine/CCL17, and intercellular adhesion molecule1 are constitutively coexpressed in dermal microvessels: a foundation for 
a cutaneous immunosurveillance system. J Immunol. (2004) 172:1575-81. doi: 10.4049/jimmunol.172.3.1575

82. Liu L, Zhong Q, Tian T, Dubin K, Athale SK, Kupper TS. Epidermal injury and infection during poxvirus immunization is crucial for the generation of highly protective T cell-mediated immunity. Nat Med. (2010) 16:224-7. doi: $10.1038 / \mathrm{nm} .2078$

83. Zhu J, Peng T, Johnston C, Phasouk K, Kask AS, Klock A, et al. Immune surveillance by CD8 $\alpha \alpha^{+}$skin-resident T cells in human herpes virus infection. Nature. (2013) 497:494-7. doi: 10.1038/nature12110

84. Ryan SJ, Carlson CJ, Mordecai EA, Johnson LR. Global expansion and redistribution of Aedes-borne virus transmission risk with climate change. PLoS Negl Trop Dis. (2019) 13:e0007213. doi: 10.1371/journal.pntd.00 07213

85. Strauss E, Levinson R, Rice C, Dalrymple J, Strauss J. Nonstructural proteins nsP3 and nsP4 of ross river and o'nyong-nyong viruses: sequence and comparison with those of other alphaviruses. Virology. (1988) 164:265-74. doi: 10.1016/0042-6822(88)90644-7

86. Smith JL, Pugh CL, Cisney ED, Keasey SL, Guevara C, Ampuero JS, et al. Human antibody responses to emerging mayaro virus and cocirculating alphavirus infections examined by using structural proteins from nine new and old world lineages. mSphere. (2018) 3:e00003-18. doi: $10.1128 / \mathrm{mSphere.00003-18}$

87. Götte B, Liu L, McInerney G. The enigmatic alphavirus non-structural protein 3 (nsP3) revealing its secrets at last. Viruses. (2018) 10:105. doi: 10.3390/v10030105

88. Shin G, Yost SA, Miller MT, Elrod EJ, Grakoui A, Marcotrigiano J. Structural and functional insights into alphavirus polyproteinprocessing and pathogenesis. Proc Natl Acad Sci USA. (2012) 109:16534-9. doi: 10.1073/pnas.1210418109

89. Malet H, Coutard B, Jamal S, Dutartre H, Papageorgiou N, Neuvonen M, et al. The crystal structures of chikungunya and venezuelan equine encephalitis virus nsP3 macro domains define a conserved adenosine binding pocket. $J$ Virol. (2009) 83:6534-45. doi: 10.1128/JVI.00189-09

90. Roundy CM, Azar SR, Rossi SL, Weaver SC, Vasilakis N. Chapter four insectspecific viruses a historical overview and recent developments. Adv Virus Res. (2017) 98:119-46. doi: 10.1016/bs.aivir.2016.10.001

91. Powers A, Brault A, Shirako Y, Strauss E, Kang W, Strauss J, et al. Evolutionary relationships and systematics of the alphaviruses. J Virol. (2001) 75:10118-31. doi: 10.1128/JVI.75.21.10118-10131.2001

92. Tan Y, Lam T, Heberlein-Larson LA, Smole SC, Auguste AJ, Hennigan S, et al. Large-scale complete-genome sequencing and phylodynamic analysis of eastern equine encephalitis virus reveals source-sink transmission dynamics in the United States. J Virol. (2018) 92:10118. doi: 10.1128/JVI.00074-18

Conflict of Interest: The authors declare that the research was conducted in the absence of any commercial or financial relationships that could be construed as a potential conflict of interest.

Copyright (c) 2020 Poh, Chan and Ng. This is an open-access article distributed under the terms of the Creative Commons Attribution License (CC BY). The use, distribution or reproduction in other forums is permitted, provided the original author(s) and the copyright owner(s) are credited and that the original publication in this journal is cited, in accordance with accepted academic practice. No use, distribution or reproduction is permitted which does not comply with these terms. 